ZOOLOGIA 31 (1): 35-41, February, 2014

http://dx.doi.org/10.1590/S1984-46702014000100005

\title{
Longer is not always better: The influence of beach seine net haul distance on fish catchability
}

\author{
Pryscilla Moura Lombardi ${ }^{1,2}$, Fábio Lameiro Rodrigues ${ }^{1} \&$ João Paes Vieira ${ }^{1}$
}

\author{
${ }^{1}$ Laboratório de Ictiologia, Instituto de Oceanografia, Universidade Federal do Rio Grande. Avenida Itália km 8, \\ 96203-900 Rio Grande, RS, Brazil. \\ ${ }^{2}$ Corresponding author. E-mail: pryscilla_lombardi@yahoo.com.br
}

\begin{abstract}
The aim of this study was to compare the influence of different haul distances of a codend beach seine on the catchability of fish in a surf zone. Two different surf zone sites (A and B) at the Cassino Beach (Rio Grande do Sul, Brazil) were sampled at three different distances, parallel to the beach $(30,60$, and $90 \mathrm{~m})$. Starting $40 \mathrm{~m}$ from the beach line, diagonal distances of approximately 50, 70, and $100 \mathrm{~m}$ were swept. The total CPUE and CPUA haul distances are compatible with a declining trend in catch rates with increased haul distance at both sites. However, statistically significant differences were observed only for the short distance CPUA $(50 \mathrm{~m})$ in relation to the other haul distances at one of the sites sampled. Two fish size groups were observed ( $T L \leqslant 40$ and $>40 \mathrm{~mm}$ ), but only small individuals $(\leqslant 40 \mathrm{~mm})$ captured in the shorter haul distance at site B showed significant differences in CPUA. This result indicates that size structure for hauls at different distances was equal and that smaller individuals determined the pattern of fish abundance. The net performance indicates that a short haul $(\leqslant 50 \mathrm{~m})$ is the best strategy to reduce net avoidance and fish escape when using this type of sampling gear.
\end{abstract}

KEY WORDS. Fish abundance; fish size; sampling gears; surf zone.

A broad variety of sampling strategies and fishing gears have been developed to collect and record the presence and abundance of different fish species occurring in estuarine and coastal marine habitats (VAn Marlen 2003, Vieira et al. 2006, Rotherham et al. 2007, Queirolo et al. 2009). According to KING (1995) and Vieira et al. (2006), the beach seine net is the most effective fishing gear for sampling in shallow, non-vegetated surf zone areas. VIEIRA et al. (2006) recommended the use of a particular beach seine net (a beach seine with a codend) for sampling estuarine environments of the Brazilian coast (Fig. 1). A number of studies have used and approved on this beach seine in estuarine and freshwater habitats in southern Brazil (e.g., Burns et al. 2006, Garcia et al. 2006, Artioli et al. 2009). However, only one record of the use of this type of gear exists for the marine surf zone in Brazil, for the southeast coast (MAzzeI et al. 2009).

Even when using the same sampling gear, the selected haul distance represent an important factor for comparing catch results. Several authors have used beach seines at surf zones, but different distances are generally applied. For example, LAYMAN (2000) and MAZZEI et al. (2009) selected a haul length of 15 $\mathrm{m}$, SiLVA et al. (2004) selected a length of $30 \mathrm{~m}$, and MonTeiroNeto \& Prestrelo (2013) selected $100 \mathrm{~m}$ hauls, hindering comparisons among different data sets. Therefore, the present study was conducted to test the performance of a beach seine net with a bag (codend) in a marine surf zone area in southern
Brazil (Fig. 3), and to identify the most effective protocol for this net in a wave-dominated environment.

\section{MATERIAL AND METHODS}

The codend beach seine used in the current study is made from a multifilament net with the following dimensions: $9 \mathrm{~m}$ in length $\times 2.4 \mathrm{~m}$ high; each wing measured $3.25 \mathrm{~m}$ in length (Fig. 1), and the codend was $3 \mathrm{~m}$ in length; the mesh in the lateral wings was $13 \mathrm{~mm}$, and the mesh in the codend was $5 \mathrm{~mm}$ (Fig. $1)$. The net was pulled by two people, with a third person holding a rope tied to the codend to prevent the bag from rising in the waves, thus hindering the process of dragging.

Starting from a fixed distance perpendicular to the beach $\left(\operatorname{Per}_{\text {dist }}=40 \mathrm{~m}\right)$, each haul was performed on a transversal line to the beach, dragging the net in the direction of the current from a depth of $1.2 \mathrm{~m}$ up to the shoreline. Three different distances parallel to the beach ( $\operatorname{Par}_{\text {dist }}$ ) were previously established (30, 60, and $90 \mathrm{~m}$; Fig. 2), and the haul distance $(\mathrm{H})$ was calculated using the Pythagorean Theorem $\left(\mathrm{H}^{2}=\operatorname{Par}_{\text {dist }}^{2}+\operatorname{Per}_{\text {dist }}^{2}\right)$ (Fig. 2). Since Per ${ }_{\text {dist }}$ was fixed at $40 \mathrm{~m}$ and $\mathrm{Par}_{\text {dist }}$ comprised 30, 60 , and $90 \mathrm{~m}$, the H estimates were 50.0, 72.1, and $98.5 \mathrm{~m}$. For simplicity, the $\mathrm{H}$ values have been referred to as 50,70 , and $100 \mathrm{~m}$ in the text. However, the original $\mathrm{H}$ values were retained for the calculation of the area swept. The standard seine width of the net was estimated to be $6 \mathrm{~m}$, and the swept area of the 


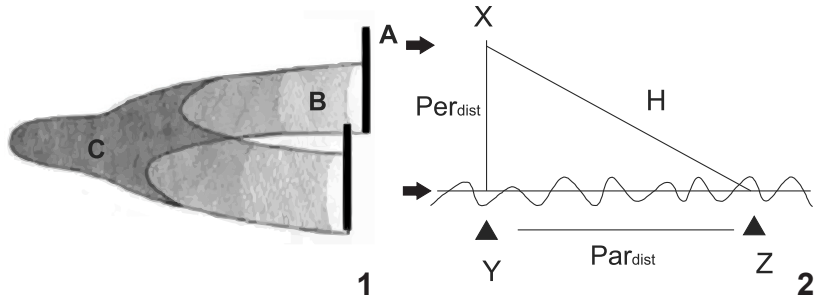

Figures 1-2. Illustrative picture of a bag seine net (1), in which " $A$ " are the poles, " $\mathrm{B}$ " are the wings and " $\mathrm{C}$ " the center sac; and (2) the sampling design, in which " $\mathrm{H}$ " represents the net trajectory.

net was calculated by multiplying $\mathrm{H}$ by 6 , which resulted in values of $300.0,432.7$, and $590.9 \mathrm{~m}^{2}$, respectively.

Sampling was conducted at two different sites (A and B) in the Cassino Beach surf zone (Fig. 3). Cassino Beach is a dissipative beach, exhibiting medium wave energy, a smooth slope with few and inexpressive beach cusps, and fine sandy sediments (Calliari 1998, Calliari et al. 2005). Sites A (32 $12^{\prime} 33.3^{\prime \prime}$, $\left.052^{\circ} 10^{\prime} 45.3^{\prime \prime} \mathrm{W}\right)$ and $\mathrm{B}\left(32^{\circ} 09^{\prime} 41.9^{\prime \prime} \mathrm{S}, 052^{\circ} 06^{\prime} 21.8^{\prime \prime} \mathrm{W}\right)$ are located $9 \mathrm{~km}$ and $500 \mathrm{~m}$ south of the west jetty of the Patos Lagoon, respectively. Despite the proximity of these two sites, LiMA \& VieIRA (2009) recorded more wave lines at site B than at site A. This variability was considered advantageous for testing the utility of this fishing gear under different conditions.

Each site was visited three times between March and April of 2009. During each visit, three random hauls were carried out for every parallel distance $\left(\mathrm{Par}_{\text {dist }}=30,60\right.$, and $\left.90 \mathrm{~m}\right)$ at each site; thus, there were nine samples per site. Each seine haul was performed immediately adjacent to the end of the previous one, but the order of parallel distances was selected at random. All fish were identified to the lowest taxonomic level using the keys by Figueiredo \& Menezes $(1980,2000)$ and; Menezes \& Figueiredo $(1980,1985)$; the specimens captured were counted and measured to the nearest millimeter (total length - TL). For each site, the number of fish caught per haul were independently expressed as catch per unit effort (individuals per sample-CPUE), which represents the number of fish caught in a single seine haul, and as catch per unit area (individuals per square meter - CPUA), which represents the number of fish caught per unit area.

Fishes were classified by size classes of $10 \mathrm{~mm}$ intervals and separated into two size groups ( $\leqslant 40 \mathrm{~mm}$ TL and $>40 \mathrm{~mm}$ TL). Based on Vieira (2006), CPUE and CPUA by size class (CPUA-SC) were calculated for individuals smaller or equal to $40 \mathrm{~mm}$ and larger than $40 \mathrm{~mm}$ TL.

Even after log transformation, the CPUE, CPUA, and CPUA-SC values did not meet the assumptions of Analyses of Variance (ANOVA) (normality and variance homogeneity); thus, a non-parametric analysis (Kruskal-Wallis test) was selected to compare the mean CPUE, CPUA, and CPUA-SC per Par dist $_{\text {for }}$ each site (at 0.05 signifficant level). The free statistics program PAST ver. 1.81 (Hammer et al. 2001) was used for these analyses.

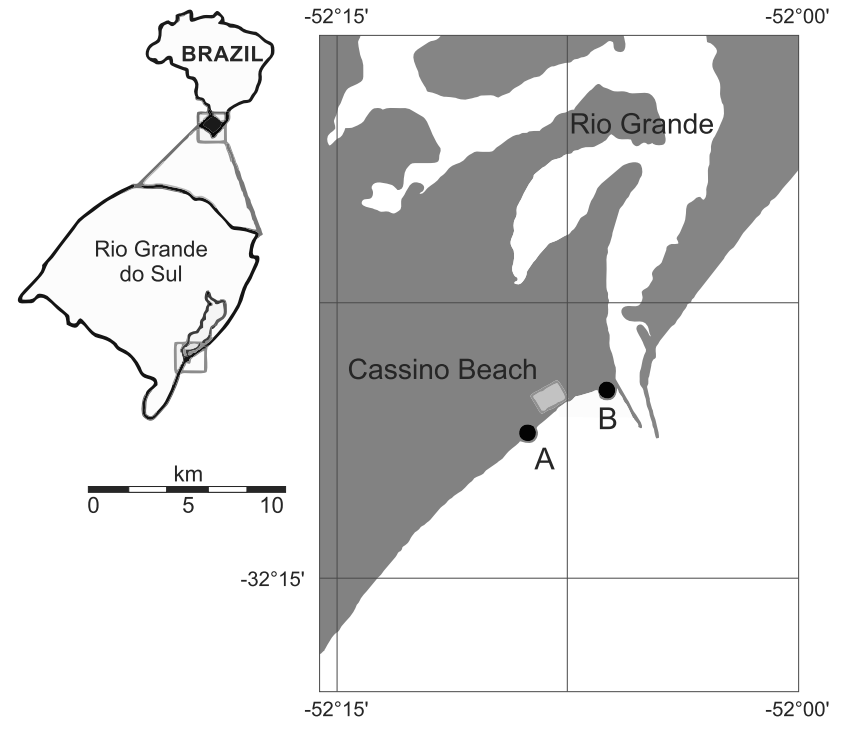

Figure 3. Geographic location of the study area, Cassino Beach, in detail, with the two sampling sites (A and B). Modified by the authors from http://www.aquarius.geomar.de (Online Map Creation).

To compare the faunistic similarity between the different haul distances, we used the minimum percentage of similarity $\left(\mathrm{P}_{\min }\right.$ ) based on CPUE\% (ARTioli et al. 2009), which was described as $\mathrm{P}_{\min }=\Sigma_{\mathrm{i}}$ minimum $\left(\mathrm{p} 1_{\mathrm{i}}\right.$ and $\left.\mathrm{p} 2_{\mathrm{i}}\right)$, where $\mathrm{p} 1_{\mathrm{i}}=$ the percentage of species $i$ in sample 1 and $\mathrm{p} 2_{\mathrm{i}}=$ the percentage of species $i$ in sample 2 (Krebs 1989). Based on the CPUE values, we calculated the numerical percentage (CPUE\%) and frequency of occurrence (FO\%) of each species, for each sampling day and each $\mathrm{Par}_{\text {dist }}$. Species that presented FO\% $\geqslant$ mean FO\% in each haul distance were considered frequent, while species with $\mathrm{FO} \%<$ mean $\mathrm{FO} \%$ were considered rare. A similar method was used for CPUE\%, in which species with CPUE\% $\geqslant$ mean CPUE\% in each seine distance were considered abundant, while species with CPUE\% < mean CPUE\% were considered not abundant. Finally, combinations of FO\% and CPUE\% allowed us to classify the species into 4 groups: abundant and frequent, frequent but not abundant, abundant but rare, and not abundant and rare (Burns et al. 2006, GarCia et al. 2006, Artioli et al. 2009, Ceni \& Vieira 2013).

Vouchers for the species collected in this study are available in the "Coleção Ictiológica da FURG".

\section{RESULTS}

The total number of fish caught during the longer haul distance $(100 \mathrm{~m})$ was less than during the shorter distances (50 and $70 \mathrm{~m}$ ), at both sites (Table I). The CPUE and CPUA at both sites showed a tendency to decrease with increased haul distance (Fig. 4). The Kruskal-Wallis post-hoc test did not reveal significant differences $(p>0.05)$ for the mean CPUE of differ- 

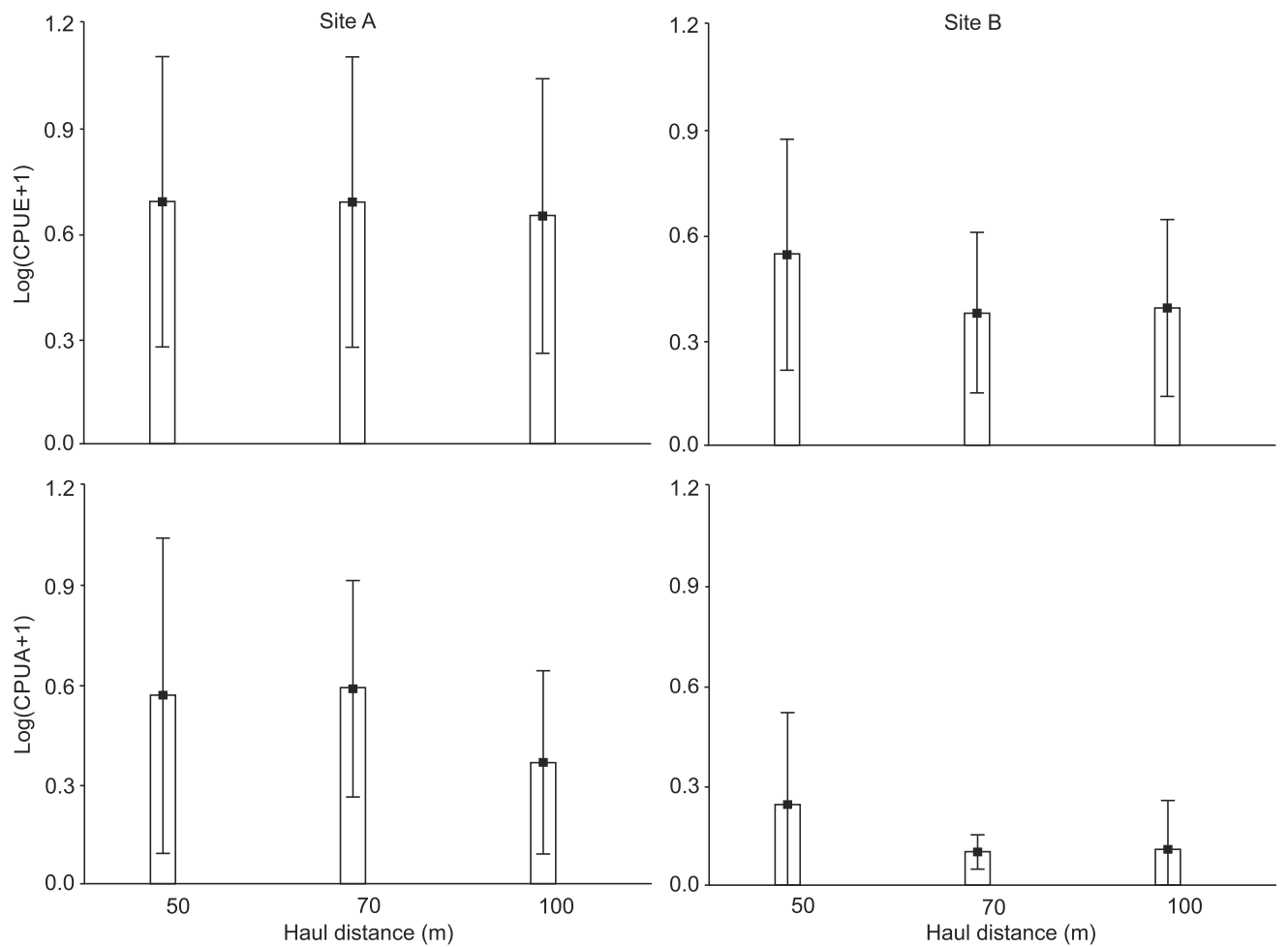

Figure 4. Variations of mean CPUE and CPUA ( $\log _{10}$ transformed) values by haul distance $(50,70$ and $100 \mathrm{~m})$ in each site (A and B). The vertical bars indicate the mean values and lines indicate the standard deviation.

Table I. Total numbers of dominant taxa in each haul distance $(50,70$ and $100 \mathrm{~m}$ ). Taxa were classified as Abundant and Frequent (bold), Frequent and Not-Abundant ( underline), Abundant and rare (italic), and the other ones are present but not frequent or abundant.

\begin{tabular}{|c|c|c|c|c|c|c|}
\hline \multirow{2}{*}{ Taxa } & \multicolumn{3}{|c|}{ Site A } & \multicolumn{3}{|c|}{ Site $B$} \\
\hline & $50 \mathrm{~m}$ & $70 \mathrm{~m}$ & $100 \mathrm{~m}$ & $50 \mathrm{~m}$ & $70 \mathrm{~m}$ & $100 \mathrm{~m}$ \\
\hline Mugil curema Valenciènnes, 1836 & 12463 & 10678 & 6366 & 1551 & 155 & 103 \\
\hline Mugil liza Valenciènnes, 1836 & 1539 & 2070 & 1117 & 564 & 256 & 1327 \\
\hline Brevoortia pectinata (Jenyns, 1842) & 1228 & 679 & 789 & $\underline{246}$ & $\underline{55}$ & $\underline{28}$ \\
\hline Mugil sp. & $\underline{922}$ & 1387 & 867 & 141 & $\underline{55}$ & $\underline{53}$ \\
\hline Clupeidae & $\underline{578}$ & $\underline{517}$ & $\underline{555}$ & 853 & 4 & 1 \\
\hline Trachinotus marginatus Cuvier, 1832 & $\underline{335}$ & $\underline{394}$ & $\underline{412}$ & $\underline{172}$ & $\underline{67}$ & 220 \\
\hline Genidens barbus (Lacepède, 1803) & 111 & $\underline{27}$ & $\underline{41}$ & 39 & 301 & $\underline{62}$ \\
\hline Atherinella brasiliensis (Quoy \& Gaimard, 1825) & $\underline{14}$ & $\underline{48}$ & $\underline{33}$ & $\underline{83}$ & $\underline{46}$ & $\underline{51}$ \\
\hline Pomatomus saltatrix (Linnaeus, 1766) & $\underline{11}$ & $\underline{5}$ & 8 & 1 & 3 & \\
\hline Engraulidae & 10 & 9 & 1 & & & \\
\hline Menticirrhus americanus (Linnaeus, 1758) & 7 & 8 & 9 & & 1 & \\
\hline Elops saurus Linnaeus, 1766 & 4 & & & & & \\
\hline Odontesthes argentinensis (Valenciennes, 1835) & 3 & 6 & 3 & 1 & 5 & 5 \\
\hline Menticirrhus littoralis (Holbrook, 1847) & 2 & 1 & & 11 & 8 & $\underline{18}$ \\
\hline Epinephelus marginatus (Lowe, 1834) & 1 & & 1 & & & \\
\hline Micropogonias furnieri (Desmarest, 1823) & 1 & 8 & 10 & & & \\
\hline Others & & 3 & 2 & 5 & 2 & 7 \\
\hline Total number & 17229 & 15840 & 10214 & 3667 & 958 & 1875 \\
\hline Species richness & 16 & 17 & 16 & 13 & 13 & 13 \\
\hline
\end{tabular}

ZOOLOGIA 31 (1): 35-41, February, 2014 
ent haul distances for either sampled site (Table II). However, the mean CPUA at site B showed significant differences between 50 and $70 \mathrm{~m}(\mathrm{p}=0.05)$, and 50 and $100 \mathrm{~m}(\mathrm{p}=0.01)$ distances (Table II).

Table II. The resulting $\mathrm{p}$ values from Kruskal-Wallis post-hoc test for CPUE and CPUA between the different haul distances (50, 70, and $100 \mathrm{~m})$, for each sampling site (A and $B)$.

\begin{tabular}{cccccc}
\hline \multirow{3}{*}{ Haul distances comparison } & \multicolumn{4}{c}{$\mathrm{p}$ values } \\
\cline { 2 - 3 } \cline { 6 - 6 } \cline { 5 - 6 } & \multicolumn{2}{c}{ CPUE } & & \multicolumn{2}{c}{ CPUA } \\
\cline { 2 - 3 } & Site A & Site B & & Site A & Site B \\
\hline $50 \times 70 \mathrm{~m}$ & 0.95 & 0.78 & & 0.66 & 0.05 \\
$50 \times 100 \mathrm{~m}$ & 0.83 & 0.73 & & 0.66 & 0.01 \\
$70 \times 100 \mathrm{~m}$ & 0.87 & 0.92 & & 0.13 & 0.08 \\
\hline
\end{tabular}

Size distribution was similar between different haul distances at both sites, ranging from $10 \mathrm{~mm}$ to $100 \mathrm{~mm}$, with peak abundance in length classes being lower than or equal to $40 \mathrm{~mm}$ TL (Fig. 5). At site A, the CPUA-SC of individuals from both size groups ( $\leqslant 40$ and $>40 \mathrm{~mm} \mathrm{TL}$ ) showed a tendency to decrease with increasing haul distance (Fig. 6); however, the Kruskal-Wallis post-hoc test did not reveal any significant differences ( $p>0.05$ ) (Table III). At site B, the CPUA-SC of small individuals ( $\leqslant 40 \mathrm{~mm} \mathrm{TL}$ ) was significantly higher at the $50 \mathrm{~m}$ haul distance when compared to 70 or $100 \mathrm{~m}$ haul distances, but there was no statistical difference between the 70 and $100 \mathrm{~m}$ haul distances. There was no significant difference in CPUASC for higher size class (> $40 \mathrm{~mm} \mathrm{TL}$ ) at site B (Table III).

Table III. The resulting $\mathrm{p}$ values from Kruskal-Wallis post-hoc test for CPUA between the different haul distances (50, 70 and 100 $\mathrm{m})$, for individuals $\leqslant 40 \mathrm{~mm}$ and $>40 \mathrm{~mm}$ in total length, for each sampling site.

\begin{tabular}{|c|c|c|c|c|}
\hline \multirow{2}{*}{ Haul distances comparison } & \multicolumn{2}{|c|}{$\mathrm{p}$ values site $\mathrm{A}$} & \multicolumn{2}{|c|}{$\mathrm{p}$ values site $B$} \\
\hline & $\leqslant 40 \mathrm{~mm}$ & $>40 \mathrm{~mm}$ & $\leqslant 40 \mathrm{~mm}$ & $>40 \mathrm{~mm}$ \\
\hline $50 \times 70 \mathrm{~m}$ & 0.86 & 0.86 & 0.01 & 0.93 \\
\hline $50 \times 100 \mathrm{~m}$ & 0.13 & 0.33 & 0.01 & 0.72 \\
\hline $70 \times 100 \mathrm{~m}$ & 0.13 & 0.21 & 0.60 & 0.54 \\
\hline
\end{tabular}

The total number of species that were collected per treatment did not differ among haul distances for both sites (Table I). At site A, the similarity among haul distances was always higher than $89 \%$, suggesting that the same proportion of the same species group was captured at all three haul distances (Table I). At site B, the similarity among distances did not exceed $51 \%$. At this site, comparison of the $50 \mathrm{~m}$ and $100 \mathrm{~m}$ haul distances showed the lowest similarity value $(<34 \%)$; this indicates that while the same species were sampled, different proportions of them were captured (Table I).
Six species were identified as abundant and frequent, but only Mugil liza Valenciennes, 1836 was abundant and frequent for all haul distances at both sites (Table I). Mugil curema Valenciennes, 1836 was abundant and frequent for all haul distances at site $\mathrm{A}$ and for distances 50 and $70 \mathrm{~m}$ at site $\mathrm{B}$, Brevoortia pectinata (Jenyns, 1842) was abundant and frequent for distances 50 and $100 \mathrm{~m}$ only at site A, Mugil sp. was abundant and frequent for distance $70 \mathrm{~m}$ at site A, Trachinotus marginatus Cuvier, 1832 was abundant and frequent for distance $100 \mathrm{~m}$ at site B, and Genidens barbus (Lacepède, 1803) was abundant and frequent for distance $70 \mathrm{~m}$ at site B (Table I). This and other species that were abundant or frequent or rare are listed in Table I.

\section{DISCUSSION}

Contrary to expectations, more individuals were captured by the shorter haul distances ( 50 and $70 \mathrm{~m}$ ) than the longer haul distances $(100 \mathrm{~m})$, even though this difference was statistically significant only at site B. The wave action, according to HAHN et al. (2007) may affect the shape of the seine and can temporarily lift lead lines or submerge float lines. Those difficulties may contribute to the differences found between the distances tested, considering that longer hauls passed through more waves than shorter hauls.

Our study showed that, while the three different haul distances $(50,70$, and $100 \mathrm{~m}$ ) caught nearly the same species, with similar abundance and frequencies at site A, species abundances and frequencies were different at site B. Evaluating the three haul distances, only CPUA and CPUA-SC for site B showed differences between the shorter haul distance and the two other for both abundance and size class. However the distribution pattern of individuals among species was similar among the efforts tested. LAYMAN (2000), using a codend seine similar to that used in the present work, but with even smaller haul distances (15 $\mathrm{m}$ and $120 \mathrm{~m}^{2}$ of swept area), also reported low diversity and few abundant but frequent species.

The same general pattern of size distribution was found at both sampling sites, with most individuals being smaller than or equal to $40 \mathrm{~mm}$ TL. The expressive dominance of the $\leqslant 40 \mathrm{~mm}$ TL size group in all sampled areas indicates that the pattern of abundance in the surf zone is dominated by small individuals. Using a larger codend seine $(26 \mathrm{~m})$ with a smaller mesh (4 mm) in Japan, SUDA et al. (2002) found primarily small juveniles (mostly smaller than $50 \mathrm{~mm} \mathrm{TL}$ ), with a few species dominating the catches. These findings are consistent with studies that found that the marine surf zone has low diversity of fish and a few highly dominant species, which comprise small transient or resident individuals that use the surf zone as a nursery area (Godefroid et al. 2003, Monteiro-Neto et al. 2003, Felix et al. 2007, Lima \& Vieira 2009, Rodrigues \& Vieira 2013).

The shorter haul distance we tested (i.e., $50 \mathrm{~m}$ ) is similar to haul distances applied in different studies at surf zone areas, 

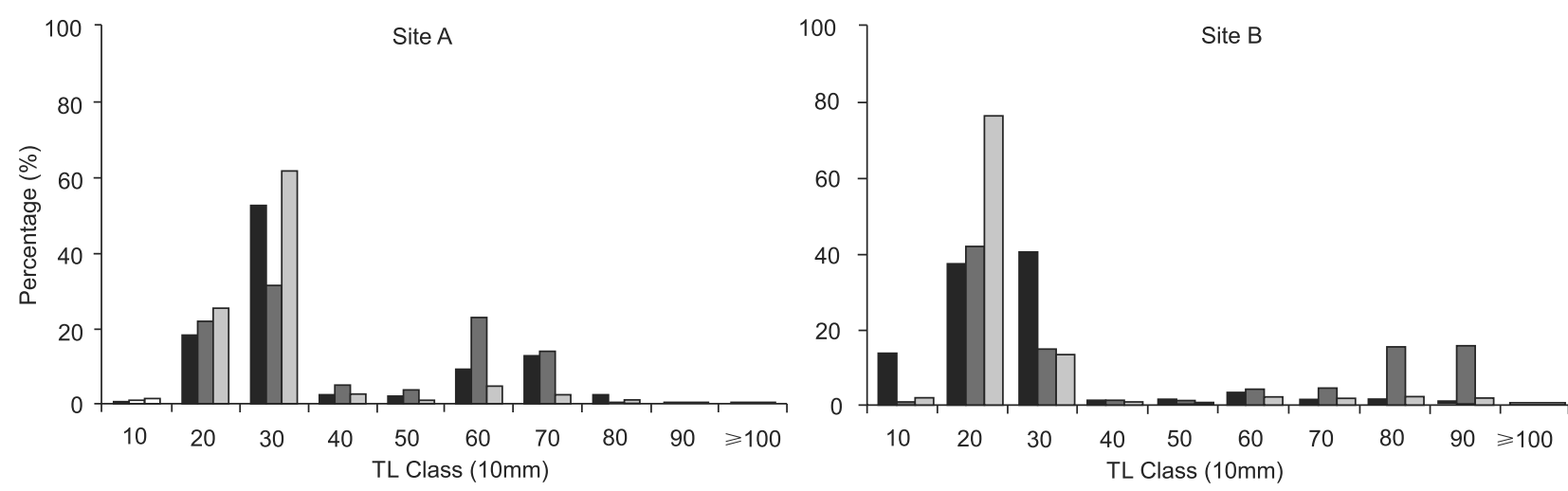

Figure 5. Percentage of individuals captured by length class for each haul distance (50, 70 and $100 \mathrm{~m})$, for each sampling site (A and B). (घ) $50 \mathrm{~m},(\square) 70 \mathrm{~m},(\square) 100 \mathrm{~m}$.
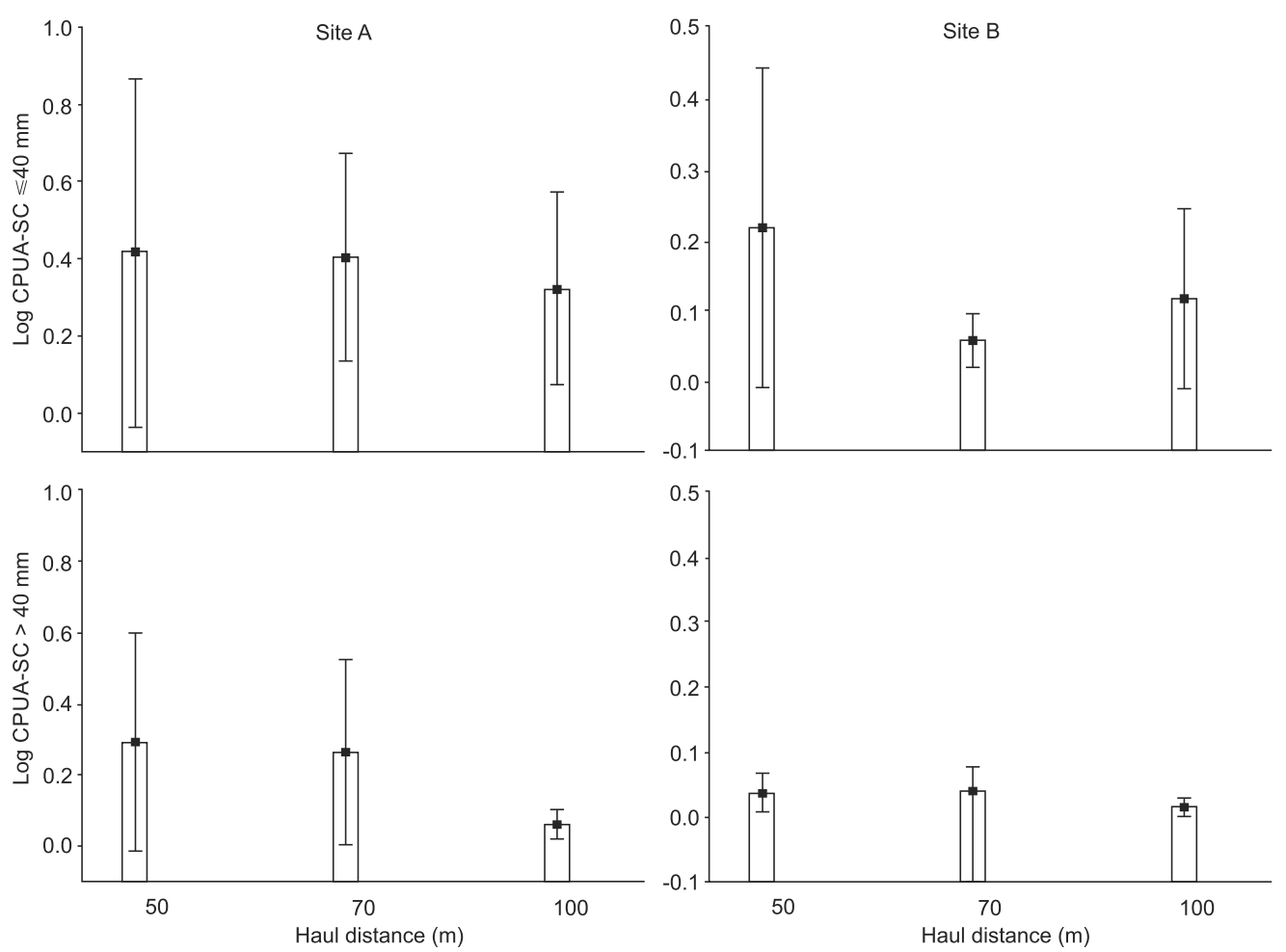

Figure 6. Variations of mean LogCPUA-SC values per haul distance for groups $\leqslant 40 \mathrm{~mm}$ and $>40 \mathrm{~mm}$ of total length (TL) in site A and site $B$. The vertical bars indicate the mean values and the lines indicate the standard deviation.

for instance: Monteiro-Neto \& Musick (1994) also used $50 \mathrm{~m}$ haul distance perpendicular to the shoreline with a small beach seine; and KANOU et al. (2004) applied a $20 \mathrm{~m}$ haul distance parallel to the shoreline, using a small bag seine net. VIEIRA et al. (2006) suggested that this particular type of $9 \mathrm{~m}$ beach seine with codend should be used for short distance hauls, in order to improve the efficiency at the haul.
Based on our results and in the literature we recommend short haul distances $(\leqslant 50 \mathrm{~m})$ as the strategy for the codend net type used in this study, since the size structure of individuals, and species composition and structure of the different haul distances are the same, shorter haul distances also take less time to be performed, becoming an economic and productive approach to surveys of fish assemblages. It is important to reg- 
ister that small beach seines without a codend, although often easier to operate in surf zones with considerable wave action, may let fish easily evade from the seine, and the codend helps to retain more fish.

\section{ACKNOWLEDGMENTS}

P.M.L. thanks a master's degree fellowship provided by Coordenação de Aperfeiçoamento de Pessoal de Nível Superior (CAPES). This work is a contribution of the Brazilian Long Term Ecological Research Program (PELD) and SISBIOTA Program from Conselho Nacional de Desenvolvimento Científico e Tecnológico (CNPq - Proc. 403805/2012-0; 563263/2010-5) and Fundação de Amparo à Pesquisa do Estado do Rio Grande do Sul (FAPERGS - Proc. 11/2262-7).

\section{LITERATURE CITED}

Artioli, L.G.S.; J.P. Vieira; A.M. Garcia \& M.A. Bemvenuti. 2009. Distribuição, dominância e estrutura de tamanhos da assembléia de peixes da lagoa Mangueira, sul do Brasil. Iheringia 99 (4): 409-418. doi: 10.1590/S0073-47212009000400011.

Burns, M.D.M.; A.M. Garcia; J.P. Vieira; A.M. Bemvenuti; D.M.L.M. MARQUES \& V. CONDINI. 2006. Evidence of habitat fragmentation affecting fish movement between the Patos and Mirim coastal lagoons in southern Brazil. Neotropical Ichthyology 4 (1): 69-72. doi: 10.1590/S1679-62252006000100006.

Calliari, L.J. 1998. Características Geomorfológicas, p. 101-104. In: U. Seeliger; C. Odebrecht \& J.P. Castello (Eds). Os ecossistemas costeiro e marinho do extremo sul do Brasil. Rio Grande, Ed. Ecoscientia.

Calliari, L.J.; T. Holand; M.S. Dias; S. Vinzon; E.B. Thorton \& T.P. Stanton. 2005. Experimento Cassino 2005: Uma síntese dos levantamentos efetuados na ante-praia e zona de arrebentação. In: Anais do Congresso da Associação Brasileira de Estudos do Quaternário. Vitória, ABEQUA, [CD].

CEnI, G. \& J.P. VieIra. 2013. Looking through a dirty glass: how different can the characterization of a fish fauna be when distinct nets are used for sampling. Zoologia 30 (5): 499505. doi: 10.1590/S1984-46702013000500005.

Félix, F.C.; H.L. Spach; P.S. Moro \& C.W. Hackradt. 2007. Ichthyofauna composition across a wave - energy gradient on southern Brazil beaches. Brazilian Journal of Oceanography 55 (4): 281-292. doi: 10.1590/S1679-87592007000400005.

Figueiredo, J.L. \& N.A. Menezes. 1980. Manual de peixes marinhos do sudeste do Brasil III. Teleostei (2). São Paulo, Museu de Zoologia Universidade de São Paulo, 93p.

Figueiredo, J. L. \& N.A. Menezes. 2000. Manual de peixes marinhos do sudeste do Brasil VI. Teleostei (5). São Paulo, Museu de Zoologia Universidade de São Paulo, 54p.

Garcia, A.M.; M.A. Bemvenuti; J.P. Vieira; D.M.L.M. Marques; M.D.M. Burns; A. Moresco \& M.V. Condini. 2006. Checklist comparison and dominance patterns of the fish fauna at
Taim Wetland, South Brazil. Neotropical Ichthyology 4 (2): 261-268. doi: 10.1590/S1679-62252006000200012.

Godefroid, R.S.; H.L. Spach; R.S. Junior \& G.M.L. Queiroz. 2003. A fauna de peixes da praia do balneário Atami, Paraná, Brasil. Atlântica 25 (2): 147-161. doi: 10.5088/at1\%C3\%A2ntica.v25i2.2302.

Hahn, P.K.J.; R.E. Bailey \& A. Ritchie. 2007. Beach Seining, p. 267-324. In: D.H. Johnson; B.M. Shrier; J.S. O’Neal; J.A. Knutzen; X. Augerot; T.A. O’Neil \& T.N. Pearsons (Eds). Salmonid Field Protocols Handbook: Techniques for Assessing Status and Trends in Salmon and Trout Populations. Bethesda, American Fisheries Society in association with state of the salmon.

Hammer, Ø.; D.A.T. Harper \& P.D. Ryan. 2001. Past: Paleontological Statistics Software Package for Education and Data Analysis. Palaeontologia Electronica 4 (1): 9p. Available online at: http://palaeo-electronica.org/2001_1/past/past.pdf [Accessed: February 2013].

Kanou, K.; M. Sano \& H. Kohno. 2004. Catch efficiency of small seine for benthic juveniles of the yellowfin goby Acanthogobius flavimanus on a tidal mudflat. Ichthyological Research 51: 374-376. doi: 10.1007/s10228-004-0231-9.

KING, M. 1995. Fisheries biology, assessment and management. Oxford, Fishing News Books, Blackwell Science, 341p.

Krebs, C.J. 1989. Ecological Methodology. New York, Harper and Row Publishers, 654p.

Layman, C.A. 2000. Fish Assemblage Structure of the Shallow Ocean Surf-Zone on the Eastern Shore of Virginia Barrier Islands. Estuarine and Coastal Shelf Science 51 (2): 201213. doi: 10.1006/ecss.2000.0636.

LimA, M.S.P. \& J.P. VIEIRA. 2009. Variação espaço-temporal da ictiofauna da zona de arrebentação da Praia do Cassino, Rio Grande do Sul, Brasil. Zoologia 26 (3): 499-510. doi: 10.1590/S1984-46702009000300014.

Mazzer, E.F.; C.R. Pimentel; R.M. Macieira \& J.C. Joyeux. 2009. Resultados preliminares da variação espacial da ictiofauna de praias arenosas sobre influência do estuário dos rios PiraquêAçê e Piraquê-Mirim, ES. IX Anais do Congresso de Ecologia do Brasil. São Lourenço: Sociedade de Ecologia do Brasil. Available online at: http://www.seb-ecologia.org.br/ 2009/resumos_ixceb/892.pdf [Accessed: 22 January 2011].

Menezes, N.A. \& J.L. Figueiredo. 1980. Manual de peixes marinhos do sudeste do Brasil IV. Teleostei (3). São Paulo, Museu de Zoologia Universidade de São Paulo, 98p.

Menezes, N.A. \& J.L. Figueiredo. 1985. Manual de peixes marinhos do sudeste do Brasil V. Teleostei (4). São Paulo, Museu de Zoologia Universidade de São Paulo, 107p.

Monteiro-Neto, C. \& J.A. Musick. 1994. Effects of beach seine on the assessment of surf-zone fish communities. Atlântica 16: 23-29.

Monteiro-Neto, C.; L.P.R. Cunha \& J.A. Musick. 2003. Community Structure of Surf-zone Fishes at Cassino Beach, Rio Grande do Sul. Brazilian Journal of Coastal Research 35: 492-501. 
Monteiro-Neto, C. \& L. Prestrelo. 2013. Comparing sampling strategies for surf-zone fish communities. Marine and Freshwater Research 64, 102-107. doi: 10.1071/MF12070.

Queirolo, D.; H. Delouche \& C. Hurtado. 2009. Comparison between dynamic simulation and physical model testing of a new trawl design for Chilean crustacean fisheries. Fisheries Research 97: 86-94. doi: 10.1016/j.fishres.2009.01.005.

Rodrigues, F.L. \& J.P. Vieira. 2013. Surf zone fish abundance and diversity at two sandy beaches separated by long rocky jetties. Journal of the Marine Biological of the United Kingdom 93(4): 867-875. doi: 10.1017/S0025315412001531.

Rotherham, D.; A.J. Underwood; M.G. Chapman \& C.A. Gray. 2007. A strategy for developing scientific sampling tools for fishery-independent surveys of estuarine fish in New South Wales, Australia. ICES Journal of Marine Science 64: 1512-1516. doi: 10.1093/icesjms/fsm096.

Silva, M.A.; F.G. Araújo; M.C.C. Azevedo \& J.N.S. Santos. 2004. The nursery function of sandy beaches in a Brazilian tropical bay for 0-group anchovies (Teleostei: Engraulidae): diel, seasonal and spatial patterns. Journal of Marine Biology Assessment UK 84: 1229-1232. doi: 10.1017/S0025315404010719h.

Suda, Y.; T. Inoue \& H. Uchida. 2002. Fish communities in the surf zone of a protected sandy beach at Doigahama, Yamaguchi Prefecture, Japan. Estuarine and Coastal Shelf Science 55: 81-96. doi: 10.1006/ecss.2001.0888.

VAn Marlen, B. 2003. Improving the selectivity of beam trawls in The Netherlands: The effect of large mesh top panels on the catch rates of sole, plaice, cod and whiting. Fisheries Research 63: 155-168. doi: 10.1016/S0165-7836(03)00075-4.

VIEIRA, J.P. 2006. Ecological analogies between estuarine bottom trawl fish assemblages from Patos Lagoon, Rio Grande do Sul, Brazil and York River, Virginia, USA. Revista Brasileira de Zoologia 23 (1): 234-247. doi: 10.1590/S010181752006000100017.

Vieira, J.P.; T. Giarrizzo \& H. Spach. 2006. Necton. In: P.C. Lana; A. Bianchini; C. Ribeiro; L.F.H. Niencheski; G. Filmann \& C.S.G. Santos (Eds). Avaliação Ambiental de Estuários Brasileiros: Diretrizes Metodológicas. Rio de Janeiro, Museu Nacional, vol. 1.

Submitted: 29.VII.2013; Accepted: 02.XI.2013.

Editorial responsibility: Cassiano Monteiro Neto 